JRTIE: Journal of Research and Thought of Islamic Education

Vol. 1, No. 1, 2018

\title{
KONSEP PENDIDIKAN ISLAM DALAM \\ PANDANGAN ADIAN HUSAINI
}

\author{
Ahmad Yazid \\ Pascasarjana UIN Sunan Kalijaga, Indonesia \\ yazidkembayan@gmail.com
}

\begin{abstract}
Education character that has been done at this time seems still unable to show its success in improving the nation character. Although it is too early to assess the success of the new idea, by looking at the various cases of moral degradation which is lately increased by students, it strengthens that character education still needs attention and improvement. By this, the government is supposed to provide the space for the education observers for contributing their thought and patching the gap that is still lacking from the character education. In this occasion, the researcher raises the thought of one of the Islamic Education form, namely Adian Husaini, discussing about his contributions aim to improve the education. By borrowing the concept of Islamic Education from Syed Muhammad Naquib Al-Attas, which bases on ta'dib, Adian Husaini arranges that Islam is the main principle in Islamic education and character education. Thus, all important aspects such as objectives, curriculum and evaluation must run according to the Islamic worldview. The hope is that education can generate the generation of believers, devout, civilized, and intelligent and noble.
\end{abstract}

Keywords : Islamic Education, Character Education, Adian Husaini.

\begin{abstract}
Abstrak: Pendidikan karakter yang telah dilaksanakan saat ini, terlihat masih belum mampu menunjukkan keberhasilannya dalam memperbaiki karakter bangsa. Meskipun terlalu dini untuk menilai keberhasilan dari gagasan yang masih berusia muda tersebut, namun dengan melihat berbagai kasus degradasi moral yang semakin marak dilakukan oleh para pelajar akhir-akhir ini, menguatkan bahwa pendidikan karakter masih perlu mendapatkan perhatian dan perbaikan. Dengan ini, maka sudah sepatutnya pemerintah memberikan ruang kepada para pemerhati pendidikan untuk menyumbangkan pemikirannya, menambal celah yang masih kurang dari pendidikan karakter. Pada kesempatan ini, peneliti mengangkat pemikiran salah satu tokoh pendidikan Islam, yaitu Adian Husaini, mengenai sumbangsihnya dalam rangka perbaikan pendidikan. Dengan meminjam konsep pendidikan Islam dari Syed Muhammad Naquib Al-Attas, yaitu berbasis pada ta'dib, Adian Husaini merumuskan bahwa Islam merupakan asas utama dalam pendidikan Islam dan pendidikan karakter. Dengan demikian, segala aspek penting seperti tujuan, kurikulum dan evaluasi pendidikan haruslah berjalan sesuai dengan pandangan hidup Islam (Islamic worldview). Harapannya, pendidikan dapat melahirkan generasi yang beriman, bertakwa, beradab, cerdas, serta berakhlak mulia.
\end{abstract}

Kata Kunci: Pendidikan Islam, Pendidikan Karakter, Adian Husaini. 


\section{A. Pendahuluan}

Permasalahan moral dan karakter bangsa masih menjadi momok menakutkan dalam dunia pendidikan di Indonesia. Berbagai peristiwa yang terjadi beberapa tahun belakangan ini memperlihatkan bahwa perbaikan karakter bangsa melalui pendidikan masih belum selesai. Menurut laporan Aji Suwignyo, ketua harian Komisi Perlindungan Anak Indonesia Samarinda, dalam kurun Januari-Oktober 2017, terdapat 320 anak terpapar aktivitas kriminalitas. ${ }^{177}$

Selain itu, berdasarkan data Kapolda di Daerah Istimewa Yogyakarta (DIY), terdapat 43 kasus kriminalitas yang melibatkan pelajar di tahun 2016.178 Dalam kasus penyalahgunaan Narkoba, Menurut Brigpol Adi Malini, peningkatan penyalahgunaan Narkoba di kalangan generasi muda, saat ini sudah mengkhawatirkan. ${ }^{179}$ Bahkan di awal tahun 2018, dunia pendidikan berduka karena peristiwa tewasnya seorang guru di tangan muridnya sendiri. ${ }^{180}$ Bahkan permasalahan lain, seperti yang disampaikan oleh Sekretaris Jenderal Forum Guru Independen Indonesia (FGII), Iwan Hermawan, bahwa maraknya kasus korupsi juga merupakan buah dari gagalnya sistem pendidikan. 181

Beberapa permasalahan di atas menunjukkan bahwa tugas pendidikan sebagai pembentuk karakter bangsa masih perlu perbaikan. Hal ini menuntut

177 Davit Styawan, “KPAI: 320 Anak Terpapar Kriminalitas, Pencegahan Tugas Orangtua, Maksimalkan Peran Rumah Aman", KPAI (Komisi Perlindungan Anak Indonesia) (23 Oktober 2017), Www.kpai.go.id/berita/kpai-320-anak-terpapar-kriminalitas-pencegahan-tugasorangtua-maksimalkan-peran-rumah-aman, diakses pada 7 Juli 2018.

178 Bagus Kurniawan, "Kapolda DIY: Sepanjang 2016, 43 Kasus Kriminal Didominasi Pelajar", Detiknews (28 Desember 2016), https://m.detik.com/news/berita/3382743/kapoldadiy-sepanjang-2016-43-kasus-kriminal-didominasi-pelajar, diakses pada 7 Juli 2018.

179 Tito Ramadhani, "Bhabinkamtibmas Polsek Pemangkat Berikan Penyuluhan Bahaya Narkoba di SMAN 1 Salatiga”, Tribun Sambas (11 Juli 2018), pontianak.tribunnews.com/2018/07/11/bhabinkamtibmas-polsek-pemangkat-berikanpenyuluhan-bahaya-narkoba-di-sman-1-salatiga, diakses pada 11 Juli 2018.

180 Kurniawan, "Siswa Pembunuh Guru di Sampang Divonis 6 Tahun Penjara", CNN Indonesia (08 Maret 2018), http://m.cnnindonesia.com/nasional//20180308165915-12281499/siswa-pembunuh-guru-di-sampang-divonis-6-tahun-penjara, diakses pada 11 Juli 2018.

181 Boy, "Korupsi Marak Bukti Kegagalan Sistem Pendidikan”, JPNN (18 Juni 2011), https://m.jpnn.com/amp/news/korupsi-marak-bukti-kegagalan-sistem-pendidikan, diakses pada 07 Juli 2018. 
segenap masyarakat, terkhusus para tokoh pemerhati pendidikan, untuk terus memikirkan solusi yang tepat dalam mengatasi permasalahan di atas. Salah satu tokoh pemikir pendidikan Islam yang menaruh perhatian besar pada permasalahan karakter bangsa adalah Adian Husaini. Adian Husaini adalah ketua program Doktor Pendidikan Islam Universitas Ibn Khaldun Bogor, peneliti Institute for the Study of Islamic Thought and Civilization (INSISTS), dan pembina Pesantren at-Taqwa di Depok. Dia termasuk yang produktif dalam menulis gagasan-gagasan pendidikan Islam untuk menjawab permasalahan yang ada saat ini. Meskipun fondasi dasar pendidikan Islam yang dia kemukakan banyak mengambil dari pemikiran Syed Muhammad Naquib AlAttas $^{182}$, namun dia mampu mengontekstualisasikan ide-ide dasar pendidikan dari tokoh terkemuka itu, ke dalam ruang pendidikan di Indonesia.

Salah satu contohnya adalah ketika Adian Husaini mengkritisi pendidikan karakter yang sedang dilaksanakan oleh pemerintah. Menurutnya, asas pendidikan karakter haruslah berdasarkan pada nilai-nilai agama dari masing-masing pemeluknya, sehingga dalam pendidikan Islam, akhlaq dan adab sudah merupakan model ideal karena sumber dan dasarnya jelas, yaitu Islam. Dalam hal ini, Adian Husaini meminjam pemikiran Syed Muhammad Naquib Al-Attas mengenai $t a^{\prime} d i b$ sebagai alternatif dari pendidikan karakter yang digaungkan oleh pemerintah Indonesia saat ini.

Selain itu, Adian Husaini juga merupakan salah satu tokoh yang turut mewarnai kontestasi perebutan wacana keislaman di Indonesia. Ia dikenal sebagai tokoh yang paling giat mengkritisi pemikiran Islam yang bercorak

182 Syed Muhammad Naquib ibn Ali ibn Abdullah ibn Muhsin Al-Attas lahir pada 5 September 1931 di Bogor, Jawa Barat. Syed Muhammad Naquib Al-Attas adalah seorang pakar yang menguasai berbagai disiplin ilmu, seperti teologi, filsafat dan metafisika, sejarah dan sastra. Ia juga seorang penulis yang produktif dan otoritatif, yang telah memberikan beberapa kontribusi baru dalam disiplin keislaman dan peradaban Melayu (Wan Mohd Nor Wan Daud, 2003: 51). Syed Muhammad Naquib Al-Attas juga pendiri sekaligus rektor ISTAC (International Institute of Islamic Thought and Civilization), Malaysia. Ia adalah orang pertama di dunia Islam kontemporer yang mendefinisikan, mengonseptualisasikan, dan menjabarkan arti, lingkup dan muatan pendidikan Islam, ide dan metode islamisasi ilmu pengetahuan kontemporer, hakikat dan pendirian universitas Islam, serta formulasi dan sistematisasi metafisika Islam dan filsafat sains dalam bentuk yang sangat sistematis dan filosofis (Wan Mohd Nor Wan Daud, 2003: 61). 
sekularisme, pluralisme dan liberalisme. Beberapa tokoh besar yang ia anggap meyakini dan menyebarkan salah satu atau kesemuanya dari ketiga paham tersebut tidak luput menjadi sasaran dari kritik seorang Adian Husaini, seperti Azyumardi Azra, Komaruddin Hidayat, Munir Mulkhan, Mukti Ali, Harun Nasution, Amin Abdullah. 183

Adian Husaini menilai bahwa tiga paham ini membawa dampak yang buruk terhadap umat Islam. Bahkan menurutnya ketiga paham ini sudah menyebar ke dalam wilayah pendidikan Islam di Indonesia. Oleh karena itu, menarik untuk mencermati bagaimana usaha Adian Husaini dalam membendung ketiga paham tersebut lewat pemikirannya mengenai pendidikan Islam.

Apabila ditelusuri lebih jauh lagi mengenai usaha Adian Husaini dalam memperbaiki pendidikan Islam, maka kita bisa melihat bahwa apa yang ia konsepkan mengenai pendidikan Islam tidak hanya berhenti pada tataran teoritis, melainkan sudah masuk pada wilayah praktis. Hal ini terbukti dari berdirinya Pesantren Tinggi At-Taqwa yang menaungi Shoul Lin (Pendidikan non formal setingkat SMP) dan Pesantren for The Studi of Islamic Thought and Civilization yang kemudian disingkat PRISTAC (setingkat SMA) di bawah binaan Adian Husaini. Kurikulum dari pesantren ini bertumpu pada tiga pokok penting, yaitu: Adab yang merupakan prioritas utama, pelajaran kitab dan silat. ${ }^{184}$

Sejauh penelusuran peneliti hingga saat ini, penelitian yang membahas pemikiran Adian Husaini masih sangat sedikit. Salah satunya adalah penelitian yang dilakukan oleh Ahmad Muttaqin mengenai rekonstruksi gagasan pluralisme, dengan menelaah salah satu karya yang ditulis oleh Adian Husaini. Ahmad Muttaqin menilai bahwa penolakan agama terhadap pluralisme sejatinya hanyalah penolakan pada dimensi teologis-filosofis, yaitu

\footnotetext{
183 Carool Kersten, Berebut Wacana: Pergulatan Wacana Umat Islam Indonesia Era Reformasi, (Bandung: Mizan, 2018), hlm. 305-307.

$184 \mathrm{http}: / /$ www.ponpes-attaqwa.com/, diakses pada 28 Agustus 2018.
} 
menempatkan berbagai agama pada derajat yang sama. ${ }^{185}$ Penelitian lainnya dilakukan oleh Amin Nasir yang berusaha untuk menyintesiskan antara pemikiran Adian Husaini dan Amin Abdullah. ${ }^{186}$ Penelitian yang dilakukan Amin Nasir berkutat pada permasalahan pemikiran keagamaan, khususnya mengenai pendekatan dalam pengkajian Islam.

Kedua judul penelitian di atas masih bergelut pada pemikiran keislaman dari tokoh Adian Husaini dan belum menyentuh pada gagasan-gagasan Adian Husaini mengenai pendidikan Islam. Oleh karena itu, selain untuk menjawab permasalahan pendidikan yang sedang terjadi, tulisan ini juga diharapkan mampu berkontribusi dalam memperkaya khazanah literatur mengenai pemikiran pendidikan Islam, khususnya pemikiran pendidikan Islam Adian Husaini.

\section{B. Biografi Adian Husaini}

Adian Husaini lahir di Bojonegoro pada 17 Desember 1965. Pendidikan formalnya ditempuh di SD-SMA di Bojonegoro, Jawa Timur. Gelar Sarjana Kedokteran Hewan diperoleh di Fakultas Kedokteran Hewan Institut Pertanian Bogor, 1989. Magister dalam Hubungan Internasional dengan konsentrasi studi Politik Timur Tengah diperoleh di Program Pasca Sarjana Universitas Jayabaya, dengan Tesis berjudul Pragmatisme Politik Luar Negeri Israel. Sedangkan gelar doktor dalam bidang Peradaban Islam diraihnya di International Institute of Islamic Thought and civilization - International Islamic University Malayasia (ISTAC-IIUM), dengan disertasi berjudul "Exclusivism and Evangelism in The Second Vatican Council: A Critical Reading of The Second Vatican Council's Documents in The Light of The Ad Gentes and Nostra Aetate". ${ }^{187}$

185 Ahmad Muttaqin, "Rekonstruksi Gagasan Pluralisme Agama: Telaah atas Buku Pluralisme Agama, Musuh-Musuh Agama Karya Adian Husaini", dalam Jurnal Al-AdYan, vol. 9, no. 1, 2014, hlm. 109.

186 Amin Nasir, "Sintesis Pemikiran M. Amin Abdullah dan Adian Husaini: Pendekatan dalam Pengkajian Islam", dalam Jurnal Fikrah, vol. 2, no. 1, 2014, hlm. 150.

187 Adian Husaini, Pendidikan Islam Mewujudkan Generasi Gemilang Menuju Negara Adidaya 2045: Kompilasi Pemikiran Pendidikan, (Depok: Yayasan Pendidikan Islam At-Taqwa, 2018), hlm. 332. 
Kini, aktivitas rutinnya adalah sebagai ketua Program Doktor Pendidikan Islam di Universitas Ibn Khaldun Bogor. Adian Husaini juga peneliti Institute for the Study of Islamic Thought and Civilization (INSISTS), dan pembina pesantren at-Taqwa di Depok. Semenjak tahun 2003 sampai saat ini, ia menjadi penulis tetap "Catatan Akhir Pekan Adian Husaini" di www.hidayatullah.com. ${ }^{188}$ Adian Husaini telah menulis beberapa buku, diantaranya berjudul Wajah Peradaban Barat: dari Hegemoni Kristen ke Dominasi Sekular-Liberal (Jakarta: Gema Insani Press, 2005), Hegemoni Kristen-Barat dalam Studi Islam di Perguruan Tinggi (Jakarta: Gema Insani Press, 2006), dan masih banyak judul-judul lainnya. Beberapa buku yang lebih khusus membahas mengenai pendidikan Islam diantaranya adalah Pendidikan Islam: Membentuk Manusia Berkarakter dan Beradab (Jakarta: Pustaka Cakrawala, 2010), Reformasi Pendidikan Menuju Negara Adidaya 2045 (E-book, www.ponpes-attaqwa.com), 10 Kuliah Agama Islam di Perguruan Tinggi (Yogyakarta, Pro-U Media, 2015)189 dan Pendidikan Islam Mewujudkan Generasi Gemilang Menuju Negara Adidaya 2045: Kompilasi Pemikiran Pendidikan (Depok: Yayasan Pendidikan Islam At-Taqwa Depok, 2018).

Jika kita membaca tulisan-tulisan Adian Husaini mengenai pendidikan Islam, maka kita bisa melihat bahwa dia mengambil fondasi dasar pemikiran pendidikan Islam dari Syed. Muhammad Naquib Al-Attas. Hal ini terlihat pada konsep Islamisasi ilmu pengetahuan, konsep $t a^{\prime} d i b$, serta banyaknya ia memasukkan pendapat Naquib Al-Attas dalam buku-bukunya.

Dalam bukunya yang berjudul Muslimlah daripada Liberal: Catatan Perjalanan di Inggris, ia mengatakan: "Saya banyak mendapatkan manfaat dari pemikiran Al-Attas tersebut dalam memahami peradaban Barat dengan lebih baik" ${ }^{190}$ Pengakuan Adian Husaini ini merupakan kewajaran, mengingat bahwa ia adalah alumni dari International Institute of Islamic Thought and civilization International Islamic University Malayasia (ISTAC-IIUM) yang didirikan oleh

\footnotetext{
188 Ibid., hlm. 333-334.

189 Ibid., hlm. 334-335.

190 Adian Husaini, Muslimlah daripada Liberal, (Jakarta: Sinergi Publishing, 2010), hlm. 23.
} 
Syed Muhammad Naquib Al-Attas. Akan tetapi, meskipun ia banyak mengadopsi pemikiran Naquib Al-Attas, ia tetap mampu mengontekstualisasikannya dengan keadaan pendidikan Islam di Indonesia.

\section{Ad-Dinul Islam sebagai Asas Pendidikan Islam}

Memaknai pendidikan Islam tidak bisa lepas dari pemaknaan kita terhadap Islam. Jika terjadi kesalahan dalam pemaknaan terhadap Islam, maka hal itu bisa memicu kesalahan-kesalahan berikutnya dalam mengonsepkan pendidikan Islam. Kesalahan yang sering terjadi dalam pemaknaan terhadap Islam, yaitu ketika Islam diartikan sebatas pengertian secara bahasa dan generik. Dalam hal ini ini, Adian Husaini mengungkapkan: "Sejumlah cendikiawan pernah mengemukakan gagasan tentang konsep Islam sebagai makna "generik". Bahwa, Islam harus dipahami dalam makna bahasa, yakni sikap tunduk dan patuh. Siapa pun yang tunduk dan patuh, dapat disebut Muslim, meskipun secara formal dia bukan beragama Islam."191

Tokoh Islam seperti Ulil Abshar Abdalla misalnya, mengartikan Islam yaitu "ketundukan", sehingga agama mana saja yang tunduk pada Tuhan juga disebut Islam. Dalam sebuah buku yang berjudul Islam Liberal dan Fundamental: Sebuah Pertarungan Wacana terdapat tulisan Ulil yang pernah dimuat dalam Harian Kompas pada 18 November 2002, yang berjudul Menyegarkan Kembali Pemahaman Islam. Ulil menyebutkan:

"Ayat Inna al-dina 'ind allah al-Islam (QS. 3: 19), lebih tepat diterjemahkan sebagai, 'sesungguhnya jalan religuisitas yang benar adalah proses-yang-tak-pernah-selesai menuju ketundukan (kepada Yang Maha Benar). Dengan tanpa rasa sungkan dan kikuk, saya mengatakan, semua agama adalah tepat berada pada jalan seperti itu, jalan panjang menuju Yang Maha Benar. Semua agama, dengan demikian adalah benar, dengan variasi, tingkat dan kadar kedalaman yang berbeda-beda dalam menghayati religuisitas itu." 192

Kesalahan dalam pemaknaan Islam, bisa menyebabkan efek domino yang akan berdampak pada kesalahan-kesalahan berikutnya, terutama ketika

191 Adian Husaini, Pendidikan Islam: Membentuk Manusia Berkarakter dan Beradab, (Jakarta: Cakrawala Publishing, 2012), hlm. 3.

192 Dzulmanni, Islam Liberal dan Fundamental Sebuah Pertarungan Wacana, (Yogyakarta: Elsaq Press, 2007), hlm. 15. 
kita ingin mengonsepkan pendidikan Islam. Dari pemaknaan Islam yang berarti tunduk dan patuh tadi melahirkan konsep pluralisme yang membuat arah dan tujuan pendidikan Islam menjadi kabur, karena hilangnya landasan Islam yang sesungguhnya. Banyak istilah lain dalam Islam yang tidak bisa diartikan hanya sekedar dari bahasa, seperti zakat yang secara bahasa adalah mensucikan, sedangkan menurut istilah adalah suatu ibadah dengan tata cara tertentu. Salat secara bahasa adalah doa, sementara secara istilah adalah suatu ibadah yang dilaksanakan dengan cara tertentu pula. Begitu pula Islam yang secara bahasa adalah "tunduk", tapi secara istilah pengertiannya adalah nama satu agama yang secara tegas disebutkan dalam Al-Qur'an dan Sunnah mengenai aspek-aspek dan persyaratannya. Dalam sebuah hadis yang diriwayatkan oleh Ibnu Umar terdapat penjelasan aspek-aspek dalam Islam:

Ibnu Umar RA berkata: Rasulullah SAW bersabda: Islam didirikan di atas lima perkara: 1) percaya bahwa tiada Tuhan selain Allah, dan bahwa Nabi Muhammad utusan Allah. 2) Mendirikan Sholat. 3) Mengeluarkan zakat. 4) Haji ke Baitullah jika kuat melakukan perjalanan. 5) Puasa bulan Ramadhan. ${ }^{193}$

Hadis Nabi Muhammad SAW yang menjelaskan tentang makna Islam di atas, sesungguhnya telah menggambarkan bagaimana konsep "Islamic worldview". Konsep syahadat menjelaskan kaitan langsung antara konsep Tuhan dalam Islam dengan konsep kenabian, sekaligus konsep wahyu dan kemudian menurun pada konsep syariat. Dalam konsep Islamic worldview, justru konsep kenabian Muhammad SAW menempati posisi sentral. Sebab hanya melalui wahyu yang diturunkan kepada Nabi Muhammad SAW, Allah SWT menjelaskan segala sesuatu tentang diri-Nya, juga tentang bagaimana tata cara manusia untuk beribadah kepada-Nya. ${ }^{194}$

Dengan pemaknaan Islam secara bahasa dan istilah seperti di atas, barulah akan menjadikan konsep pendidikan Islam menjadi lebih terarah dan jelas. Karena Islam bukanlah semua agama yang mengajarkan ketundukan pada Tuhan, tapi Islam adalah agama yang dibawa oleh Rasulullah

\footnotetext{
${ }^{193}$ HR. Bukhari dalam Muhammad Fu'ad Abdul Baqi, Al-Lu'Lu' Wal Marjan: Shahih BukhariMuslim, (Jakarta: Elex Media Komputindo, 2017), hlm. 6.

194 Husaini, Pendidikan Islam......, hlm. 7-8.
} 
Muhammad SAW, yang telah ditetapkan dalam Al-Qur'an dan Sunnah, dan hanya mengimani Allah SWT, satu-satunya Tuhan yang wajib diibadahi. Ketika kita meyakini bahwa Islam satu-satunya agama yang benar, maka konsep pendidikan Islam tidak akan lari kepada sekulerisasi dan liberalisasi. Menjadikan Islam -dengan pengertian yang sesungguhnya- sebagai asas pendidikan Islam akan melahirkan gagasan Islamisasi ilmu pengetahuan, karena segala ilmu yang ada akan difilter terlebih dahulu dengan sudut pandang Islam.

\section{D.Tujuan Pendidikan Islam}

Tujuan pendidikan Islam sejatinya bersifat holistik, menjalin keterhubungan antara makhluk, alam semesta dan Sang Pencipta. Tujuan utamanya adalah membangun kesadaran peserta didik bahwa dia adalah makhluk ciptaan Tuhan sehingga memiliki tugas dan fungsi yang sudah ditetapkan padanya. ${ }^{195}$ Dalam merumuskan tujuan pendidikan Islam, Adian Husaini sependapat dengan tujuan pendidikan Islam yang telah dirumuskan Syed Muhammad Naquib Al-Attas, bahwa:

"Tujuan pendidikan Islam adalah untuk menghasilkan menusia-manusia yang baik. Apa yang diartikan 'baik' dalam konsep kita tentang 'orang baik'? Unsur fundamental yang berpautan dalam konsep pendidikan Islam adalah menanamkan adab, karena adab dalam pengertian yang mencakup semuanyalah di sini dimaksudkan sebagai meliputi kehidupan spiritual dan material manusia yang memberikan sifat kebaikan yang dicarinya". 196

Jadi, tujuan pendidikan adalah menghasilkan manusia yang baik. Manusia yang baik di sini adalah manusia yang beradab. Jadi istilah yang pendidikan yang digunakan di sini lebih tepatnya adalah $\mathrm{ta}^{\prime} \mathrm{dib}$, bukan $\mathrm{ta}^{\prime} \mathrm{lim}$ atau tarbiyah. Penekanannya tidak hanya sekedar pada penguasaan ilmu pengetahuan, tapi juga perubahan sikap dan perilaku. Tidak hanya itu, menanamkan adab sebagai tujuan pendidikan juga harus berasaskan pada

\footnotetext{
${ }^{195}$ Imam Syafe'i, “Tujuan Pendidikan Islam”, dalam Jurnal Al-Tadzkiyyah: Jurnal Pendidikan Islam, vol. 6, no. 2, 2015, hlm. 164-165.

196 Syed Muhammad Al-Naquib Al-Attas, Islam dan Sekularisme, (Bandung: Penerbit Pustaka Perpustakaan Salman, 1981), hlm. 221-222.
} 
ajaran Islam, sebagaimana telah disebutkan sebelumnya bahwa Islam adalah asas dari pendidikan Islam. Adian Husaini, lebih lanjut menjelaskan bahwa:

'Orang baik' atau orang shalih atau good man, bisa dikatakan sebagai manusia yang memiliki berbagai nilai keutamaan dalam dirinya. Dengan berpijak pada konsep adab dalam Islam, maka 'manusia yang baik' atau 'manusia yang beradab', adalah manusia yang mengenal Tuhannya, mengenal dan mencintai Nabinya, menjadikan Nabi saw sebagai uswah hasanah, menghormati ulama sebagai pewaris nabi, memahami dan meletakkan ilmu pada tempat yan terhormat - paham mana ilmu yang fardu ain, dan mana yang fardu kifayah; juga mana ilmu yang bermanfaat dan ilmu yang merusak dan memahami serta mampu menjalankan tugasnya sebagai khalifatullah fil-ardh dengan baik. 197

Sebenarnya tujuan pendidikan Islam yang telah dijelaskan di atas, sejalan dengan Tujuan Pendidikan Nasional Indonesia. Dalam Undang-Undang Nomor 20 Tahun 2003 tentang Sistem Pendidikan Nasional Bab II Pasal 3 disebutkan bahwa pendidikan nasional adalah bertujuan untuk berkembangnya potensi peserta didik agar menjadi manusia yang beriman dan bertakwa kepada Tuhan Yang Maha Esa, berkahlak mulia, sehat, berilmu, cakap, kreatif, mandiri dan menjadi warga negara yang demokratis serta bertanggung jawab. ${ }^{198}$ Melihat kesamaan antara tujuan pendidikan Islam dan tujuan pendidikan Nasional Indonesia, maka sudah sepatutnya tidak terdapat pertentangan di antara keduanya ketika berada dalam wilayah pelaksanaan. Manusia yang baik, beradab, dan berakhlak mulia versi negara harus juga merupakan manusia yang baik, beradab, dan berakhlak mulia dalam menurut Islam. ${ }^{199}$ Di dalam Islam, pembahasan mengenai adab dan akhlak mulia begitu lengkap, sehingga rumusan dan pelaksanaan pembentukan adab ini haruslah berdasar pada ajaran Islam. Oleh karena itu, pemerintah dalam hal ini cukup merumuskan, memfasilitasi, dan mengevaluasi penerapan konsep adab dan ta'dib dalam umat Islam. Sementara bentuk dan teknis pelaksanaan di lapangan, diserahkan kepada pihak pelaksana. 200

${ }^{197}$ Husaini, Pendidikan Islam......, hlm. 70.

198 Bab II Pasal 3 Undang-Undang Nomor 20 Tahun 2003 tentang Sistem Pendidikan Nasional.

${ }^{199}$ Husaini, Pendidikan Islam Mewujudkan....., hlm. 17.

200 Ibid., hlm. 24. 


\section{E. Kurikulum Pendidikan Islam}

Secara bahasa, kurikulum berasal dari bahasa Yunani, yaitu curir dan curere yaitu tempat berpacu atau berlari dalam sebuah perlombaan dengan rute yang sudah ditentukan untuk ditempuh oleh para kompetitor. ${ }^{201}$ Sedangkan dalam pengertian luasnya, kurikulum bisa dimaknai dalam tiga konteks, yaitu sebagai sejumlah mata pelajaran yang harus dipelajari oleh peserta didik, sebagai pengalaman belajar dan sebagai rencana program belajar. ${ }^{202}$ Selain itu, kurikulum juga berfungsi sebagai alat untuk mencapai tujuan pendidikan. ${ }^{203}$

Telah disebutkan pada pembahasan sebelumnya bahwa tujuan pendidikan Islam adalah untuk membentuk manusia beradab. Oleh karenanya, kurikulum pendidikan Islam haruslah mengarah pada tujuan yang telah dirumuskan. Menurut Adian Husaini:

kurikulum itu menempatkan adab sebagai basis pendidikan, dilanjutkan dengan penekanan pada penguasaan ilmu-ilmu fardu ain dan fardu kifayah secara proporsional."204 ... adab dan ilmu-ilmu fardu ain diletakkan sebagai kurikulum inti. Ko-kurikulernya adalah serangkaian praktik ibadah, zikir, shadaqah, dan lain-lain, untuk menguatkan target kurikulernya. Sedangkan ilmu-ilmu yang bersifat fardu kifayah dan seterusnya ditempatkan sebagai 'ekstra-kurikuler', yang diajarkan sesuai dengan kemampuan murid dan keperluan umat. 205

Ketika kurikulum pendidikan Islam menempatkan adab, akhlak mulia, keimanan, ketakwaan dan kecerdasan pada tujuan pendidikan, maka sudah sepatutnyalah semua aspek mendapatkan perhatian yang serius dalam evaluasi pendidikan. Peserta didik yang masih buruk dalam hal adab dan ibadahnya, tidak bisa diluluskan ke tahap selanjutnya. Adian Husaini mengatakan, penanaman keimanan, pelaksanaan berbagai ibadah wajib, haruslah menjadi kurikulum inti dan secara otomatis juga dijadikan sebagai standar utama kelulusan siswa. ${ }^{206}$ Artinya, peserta didik yang akan dianggap lulus adalah peserta didik yang kokoh keimanannya, baik ibadahnya, bagus akhlaknya,

201 Ali Mudlofir, Aplikasi Pengembangan Kurikulum Tingkat Satuan Pendidikan (KTSP) dan Bahan Ajar dalam Pendidikan Agama Islam, (Jakarta: Rajawali Press, 2012), hlm. 1.

202 Ibid., hlm. 3.

${ }^{203}$ Ibid., hlm. 4.

${ }^{204}$ Husaini, Pendidikan Islam Mewujudkan......, hlm. 57.

205 Ibid., hlm. 57.

206 Ibid., hlm. 80. 
serta cerdas akalnya. Sementara peserta didik yang tidak memenuhi standar di atas, maka belum boleh untuk diluluskan.

Selain itu, beberapa masalah yang masih terjadi dalam kurikulum pendidikan Islam, yaitu ketika kurikulum diturunkan menjadi satuan materi pembelajaran. Selama ini, materi pembelajaran yang dipelajari oleh peserta didik, seringkali didominasi oleh ilmu pengetahuan hasil epistemologi Barat yang bercorak sekuler. Dalam pembahasan kurikulum ini, maka pembahasan mengenai epistemologi menjadi penting, terutama perbedaan antara epistemologi Barat dan Islam.

Secara bahasa, epistemologi berasal dari kata Yunani yaitu episteme yang artinya ilmu pengetahuan dan logos yang artinya pengetahuan, sehingga epistemologi berarti pengetahuan tentang pengetahuan atau teori pengetahuan. Ada dua pertanyaan yang harus dijawab ketika membahas epistemologi, yaitu “apa yang dapat diketahui?" dan “bagaimana cara mengetahuinya?" 207

Dalam Islam, pengetahuan dikenal dengan istilah $\mathrm{Ilm}$. Ilm itu sendiri bermakna pengetahuan yang umum dan luas, mencakup ilmu-ilmu yang bersifat empiris, rasional dan mistis. ${ }^{208}$ Jadi sedari awal, tidak ada istilah dikotomi pengetahuan dalam Islam, baik pengetahuan yang sifatnya fisik maupun metafisik. Adian Husaini, Dkk, menjelaskan bahwa epistemologi Islam mengakui empat sumber ilmu sekaligus, yaitu: indera, akal, intuisi, dan wahyu. Masing-masing sumber tersebut memiliki kadar kemampuan yang berbeda sehingga mereka tidak bisa dipisah-pisah dan harus digunakan secara proporsional. ${ }^{209}$ Hal ini tentu saja berbeda dengan konsep epistemologi Barat yang sekuler. Barat meletakkan kebenaran yang berasal dari rasio dan empiris sebagai sumber pengetahuan tertinggi. Sementara Islam, menjadikan sumber pengetahuannya tidak hanya berlandaskan pada akal dan pengalaman saja,

\footnotetext{
207 Suparlan Suhartono, Filsafat Ilmu Pengetahuan, (Jogjakarta: Ar-Ruzz Media, 2016), hlm. 117.

${ }^{208}$ Haidar Bagir, Epistemologi Tasawuf: Sebuah Pengantar, (Bandung: Mizan, 2017), hlm. 47.

${ }^{209}$ Adian Husaini, dkk., Filsafat Ilmu; Perspektif Barat dan Islam, (Jakarta: Gema Insani Press, 2015), hlm. 48.
} 
tetapi juga bersandar pada wahyu. Beberapa materi yang disayangkan oleh Adian Husaini, yang masih masuk dalam materi pembelajaran yang dipelajari oleh peserta didik, yaitu materi evolusi. Menurut Adian Husaini, sepatutnya, para murid diajarkan bahwa mereka adalah keturunan Nabi Adam yang tujuan hidupnya adalah untuk beribadah kepada Allah. ${ }^{210}$ Tentu saja ini menjadi perhatian oleh para pendidik, juga pemegang kebijakan pendidikan dalam dunia pendidikan Islam, agar memerhatikan setiap materi yang diberikan kepada peserta didik. Jangan sampai materi yang diberikan malah jelas-jelas bertentangan dengan wahyu, baik itu dalam Al-Quran maupun Hadis, serta kesepakatan para ulama.

\section{F. Pendidikan Karakter Berbasis $T a^{\prime} d i b$}

Permasalahan yang tiada henti dalam kehidupan masyarakat di Indonesia seperti tindak kriminal dan kasus korupsi, memperlihatkan bahwa kualitas manusia Indonesia masih belum baik. Berbagai pengamat dan pemikir mencari akar dari permasalahan, sekaligus formula untuk mengobati penyakit masyarakat Indonesia tersebut. Salah satu dugaan kuat mengenai permasalahan di atas adalah permasalahan karakter bangsa, yang saat ini mulai memudar pada setiap individu. Rusaknya moral dan karakter tentu saja tidak bisa dilepaskan dari rendahnya kualitas pendidikan yang seharusnya punya perhatian serius terhadap penanaman nilai-nilai yang baik. Dalam sebuah buku yang berjudul "Pendidikan Untuk Transformasi Bangsa: Arah Baru Pendidikan untuk Perubahan Mental Bangsa, Ace Suryadi dkk, mengatakan bahwa:

Faktor utama terjadinya permasalahan karakter bangsa adalah karena rendahnya kualitas pendidikan itu sendiri. Pendidikan yang tidak berkualitas tidak mampu menawarkan program dan strategi yang berdampak jangka panjang bagi tumbuhnya karakter seorang atau kolektif. Pendidikan yang tidak bermutu tidak mampu menwarkan upaya preventif untuk mencegah degradasi moral dan karakter dalam masyarakat. ${ }^{211}$

${ }^{210}$ Husaini, Pendidikan Islam Mewujudkan....., hlm. 74.

211 Ace Suryadi, Dkk, Pendidikan untuk Transformasi Bangsa: Arah Baru Pendidikan untuk Perubahan Mental Bangsa, (Jakarta: Kompas, 2014), hlm. 73. 
Mengenai permasalahan di atas, Menteri Pendidikan di era pemerintahan sebelumnya yaitu Mohammad Nuh mencanangkan pendidikan karakter yang termuat dalam kurikulum 2013, yang saat ini sudah dilaksanakan dalam dunia pendidikan. Dalam buku 'Panduan Pelaksanaan Pendidikan Karakter' dijelaskan bahwa pendidikan karakter ditempatkan sebagai landasan untuk mewujudkan visi pembangunan nasional, yaitu mewujudkan masyarakat berakhlak mulia, bermoral, beretika, berbudaya, dan beradab beradasarkan falsafah Pancasila. ${ }^{212}$

Dalam bukunya yang berjudul "Menyemai Kreator Peradaban: Renungan Tentang Pendidikan, Agama dan Budaya", terkait dengan pendidikan karakter, Muhammad Nuh menyebutkan ada tiga kelompok pendidikan karakter, yaitu: (1) pendidikan karakter yang menumbuhkan kesadaran sebagai makhluk dan hamba Tuhan Yang Maha Esa, (2) Pendidikan karakter yang terkait dengan keilmuan, dan (3) pendidikan karakter yang menumbuhkan rasa cinta dan bangga menjadi bangsa Indonesia. 213

Adian Husaini mengapresiasi gagasan dan pelaksanaan pendidikan karakter ini. Dan jika kita melihat karakter yang diangkat untuk ditanamkan pada peserta didik sejatinya selaras dengan pendidikan karakter yang disampaikan di dalam Al-Qur'an. Nilai karakter seperti religius, jujur, toleransi, disiplin, kerja keras, kreatif, mandiri, demokratis, rasa ingin tahu, semangat kebangsaan, cinta tanah air, menghargai prestasi, bersahabat, cinta damai, gemar membaca, peduli lingkungan dan sosial, serta tanggung jawab yang dilaksanakan dalam pendidikan karakter juga relevan dengan ayat-ayat dalam Al-Qur'an. ${ }^{214}$

Hanya saja, Adian Husaini masih mempertanyakan pendidikan karakter seperti apa yang akan dilaksanakan oleh pemerintah. Menurutnya, pendidikan

212 Panduan Pelaksanaan Pendidikan Karakter, (Jakarta: Kementerian Pendidikan Nasional Badan Penelitian dan Pengembangan Pusat Kurikulum dan Perbukuan, 2011), hlm. 1.

213 Mohammad Nuh, Menyemai Kreator Peradaban: Renungan tentang Pendidikan, Agama dan Budaya, (Jakarta: Zaman, 2013), hlm. 19.

214 Budihardjo dan Novi Tazkiyatun Nihayah, "The Character Education Values In Qur'anic Verses", dalam Jurnal Studi Islam, vol. 17, no. 2, 2016, hlm. 111. 
karakter yang akan diberikan kepada peserta didik Muslim (khususnya), haruslah pendidikan karakter yang berbasis pada Tauhid. Hal inilah nantinya yang akan membedakan antara karakter yang dimiliki oleh bangsa lain, dengan karakter yang dimiliki oleh bangsa Indonesia, khususnya pada masyarakat Muslim. ${ }^{215}$

Sebenarnya konsep pendidikan karakter yang diterapkan pemerintah dalam lembaga pendidikan bukanlah hal yang asing dalam Islam. Jauh sebelum pendidikan karakter dicanangkan, Islam sudah lebih dulu menerapkan hal yang serupa dalam kehidupan. Dalam Islam, istilah karakter ini tidak dikenal, tapi yang dikenal adalah akhlaq dan satu lagi yaitu adab. Jika karakter lebih bersifat umum dan landasannya tergantung dimana diterapkannya, maka adab dalam Islam adalah sudah jelas landasannya, begitupula sumber nilainya. Adab akan memiliki ciri tersendiri dan dimanapun nilai serta landasannya akan tetap sama yaitu Islam. Jadi dalam Islam, pendidikan karakter saja tidak cukup namun harus ditambah pula dengan adab.

Bagi Muslim, berkarakter saja tidaklah cukup. Beda antara Muslim dan non-Muslim -meskipun sama-sama berakarakter- adalah pada konsep adab. Kaum Muslim Indonesia saat ini bukan hanya dituntut untuk menjadi seorang yang berkarakter, tetapi harus menjadi seorang yang berkarakter dan beradab. ${ }^{216}$

Di Indonesia, kata "adab" bukanlah hal yang asing. Di dalam pancasila, terutama pada sila kedua disebutkan "kemanusiaan yang adil dan beradab". Oleh karena itu, di Indonesia sendiri sudah mencita-citakan manusia-manusia yang beradab. Sayangnya, dalam sejarah, pemaknaan terhadap pancasila dimonopoli oleh berbagai kepentingan. Bagi partai politik, pancasila ditafsirkan untuk kepentingan mereka, bahkan berbagai agama berebut untuk menafsirkan pancasila dan menggunakannya untuk kepentingan pribadi. Bahkan dalam

\footnotetext{
${ }^{215}$ Adian Husaini, "Pendidikan Karakter Berbasis Ta'dib", dalam Jurnal TSAQAFAH, vol. 9, no. 2, 2013, hlm. 377.

${ }^{216}$ Husaini, Pendidikan Islam......, hlm. 46.
} 
pemahaman kebanyakan masyarakat Indonesia, adab adalah hanya sekedar kesopanan dan kelakuan yang baik sesuai budaya setempat. Di dalam Kamus Lengkap Bahasa Indonesia, "adab diartikan sebagai sopan, kesopanan, kebaikan, budi pekerti". 217 Oleh karena itu, pemahaman yang terlalu sederhana dan tidak memiliki pijakan yang kuat, menjadikan terma adab ini menjadi rapuh. Salah satu cara agar terma adab ini menemui pijakannya adalah mengembalikan terma adab ini kepada Islam. Jika kita mau jujur, istilah adil dan beradab itu adalah istilah yang berasal dari bahasa Arab dan disinggung dalam Al-Qur'an maupun Hadis. Adian Husaini, menyebutkan bahwa:

Indikasi yang lebih jelas tentang kuatnya pandangan dunia Islam pada rumusan pancasila adalah terdapatnya sejumlah kata kunci yang maknanya sangat khas dalam Islam. Ambil contoh, kata "adil", "adab", "hikmah", dan "musyawarah". Dua kata adil dan adab - ini jelas berasal dari kosakata Islam, yang memiliki makna khusus (istilahan) dan hanya bisa dipahami dengan tepat jika dirunut pada pandangan-dunia Islam. Kedua istilah tersebut jelas tidak ditemukan dalam tradisi Indonesia asli, sebelum kedatangan Islam. ${ }^{218}$

Istilah adab juga merupakan salah satu dasar Islam. Para ulama telah banyak membahas makna adab dalam pandangan Islam. Istilah adab bisa ditemukan dalam sejumlah hadis Nabi SAW. misalnya, Anas R.A. meriwayatkan, bahwa Rasulullah SAW pernah bersabda: "Akrimuu auladakum, wa-ahsinuu adabahum". Artinya : muliakanlah anak-anakmu dan perbaikilah adab mereka. (HR Ibn Majah). Sejumlah ulama juga menulis kitab terkait dengan adab, seperti al-Mawardi (w. 450 H), menulis Adab ad-Dunya wa ad-Din, Muhammad bin Sahnun at-Tanwukhi (w.256 H) menulis Adab al-Mu'allimin wa al-Muta'allimin, juga al-Khatib al-Baghdadi (w.463 H) menulis al-jami' li-Akhlaq al-Rawi wa Adab as-Sami' ${ }^{219}$

Jadi, konsep adab dalam Islam memang sangat terkait dengan pemahaman tentang wahyu. Orang beradab adalah yang dapat memahami dan meletakkan sesuatu pada tempatnya, sesuai dengan harkat dan martabat yang

217 Tri Kurnia Nurhayati, Kamus Lengkap Bahasa Indonesia, (Jakarta: Eska Media Press, 2005), hlm. 8 .

218 Adian Husaini, Pancasila Bukan Untuk Menindas Hak Konstitusional Umat Islam, (Jakarta: Gema Insai Press, 2009), hlm. 214.

219 Husaini, Pendidikan Islam......, hlm. 47. 
ditentukan oleh Allah SWT. Dalam ajaran agama Islam, yang dimaksud dengan masyarakat beradab adalah masyarakat yang memuliakan orang yang berilmu, orang yang shalih, dan orang yang takwa; bukan orang yang kuasa, bayak harta, keturunan raja, berparas rupawan, dan banyak anak buah. ${ }^{220}$ Selain itu, hal lain yang ditakutkan oleh Adian Husaini mengenai pendidikan karakter, yaitu program yang hanya berujung pada slogan semata dan masih saja tetap tidak berubah. Adian Husaini, menyebutkan:

"Kita patut khawatir, bahwa program pendidikan karakter ini juga nantinya akan berujung pada slogan semata. Ganti menteri, ganti kebijakan. Lihatlah, bagaimana pergantian kurikulum dan buku pelajaran yang datang silih berganti, ada kurikulum Berbasis Materi (KBM), ada Kurikulum Berbasis Kompetensi (KBK), dan sebagainya. Lihatlah, berbagai slogan dan operasi dibuat untuk kelancaran lalu-lintas, tetapi hingga kini, program itu berujung menjadi slogan".221

Sejatinya, pendidikan karakter tidak hanya cukup diajarkan secara teori dan dihafalkan. Pendidikan karakter akan terwujud dengan keteladanan. Guru di sekolah tidak hanya bertugas menjadi pengajar, akan tetapi juga menjadi teladan. Tidak sembarangan orang bisa menjadi guru. Guru yang didalam dirinya sudah tertanam karakter yang baik sajalah yang bisa ditugaskan di sekolah, karena di sekolah nantinya dia bisa menjadi teladan bagi muridmuridnya. Sekali lagi hal ini akan terwujud bila kita menyadari betul perlunya karakter. Tapi jika tidak, siapa saja bisa menjadi guru, tidak peduli akhlak, moral dan sikapnya baik atau tidak, yang penting ia bisa mengajarkan pengetahuan kepada muridnya. Penulis pikir, inilah yang masih sulit untuk dilaksanakan dalam dunia pendidikan kita. Mencari guru yang mau berkorban dan siap menjadi teladan, bukanlah perkara yang mudah, karena sekarang kita berada di masa materialisme, dimana seorang tidak akan bekerja jika tidak dibayar dengan materi yang disetujui. Sehingga pekerjaan yang akan ia lakukan, hanyalah pekerjaan yang sesuai dengan materi yang diterima, bukan atas dasar pengorbanan dan semangat untuk berbagi.

\footnotetext{
${ }^{220}$ Husaini, Pancasila Bukan untuk Menindas....., hlm. 225.

${ }^{221}$ Husaini, Pendidikan Islam......, hlm. 38.
} 


\section{G. Kesimpulan}

Dengan meletakkan Islam sebagai asas utama dalam pendidikan, maka setiap aspek penting dalam pendidikan, seperti tujuan dan kurikulum akan dikonsepkan serta dilaksanakan berdasarkan cara pandang Islam. Dalam pelaksanaannya, pendidikan Islam yang bertujuan untuk membentuk manusia beradab juga akan berpedoman pada ajaran Islam. Dengan asas itu pula, kurikulum pendidikan Islam, terkhusus dalam aspek materi pembelajaran, haruslah sesuai dengan keyakinan umat Islam. Jangan sampai ada materi pembelajaran yang berpotensi untuk melemahkan keyakinan peserta didik dalam meyakini agamanya. Harapannya, dengan konsep pendidikan yang seperti ini, pendidikan Islam dapat melahirkan peserta didik yang beriman, bertakwa, beradab dan berakhlak mulia, sesuai dengan ajaran Islam.

Pendidikan adab dan akhlaq sebagai usaha untuk menyukseskan pendidikan karakter yang digaungkan oleh pemerintah haruslah mengedepankan keteladanan, baik itu dari orang tua maupun guru. Orang tua dari peserta didik haruslah diberi pemahaman mengenai adab, begitu juga guru yang akan mengajar di sekolah. Jadi pihak sekolah harus menjalin komunikasi yang baik antara guru dan orang tua untuk saling berbagi pemahaman mengenai adab. Hal ini nantinya juga akan berdampak pada evaluasi pembelajaran. Adab akan menjadi tolak ukur pertama dalam kelulusan peserta didik, bukan hanya sekedar kemampuan memahami materi pembelajaran saja. Jika adab peserta didik terhadap orang tua atau guru misalnya tidak baik, maka peserta didik itu tidak boleh diluluskan untuk tingkat selanjutnya, karena adab merupakan indikator utama keberhasilan peserta didik dalam kegiatan pembelajaran. Kurikulum yang berupa materi pembelajaran juga harus memuat hikmah dan nilai dari ilmu yang disampaikan juga keteladanan dari tokoh-tokoh yang dipelajari. Hal ini menuntut para guru untuk lebih kreatif dalam mengembangkan materi ajar, serta memasukkan materi yang bisa merangsang aspek kognisi serta afeksi peserta didik untuk menjadi orang yang beradab dan berakhlaq. 
JRTIE: Journal of Research and Thought of Islamic Education

Vol. 1, No. 1, 2018

\section{DAFTAR PUSTAKA}

Attas, Syed Muhammad Al-Naquib, Islam dan Sekularisme, Bandung: Penerbit Pustaka Perpustakaan Salman, 1981.

Bagir, Haidar, Epistemologi Tasawuf: Sebuah Pengantar, Bandung: Mizan, 2017.

Baqi, Muhammad Fu'ad Abdul, Al-Lu'Lu' Wal Marjan: Shahih Bukhari-Muslim, Jakarta: Elex Media Komputindo, 2017.

Budihardjo dan Nihayah, Novi Tazkiyatun, "The Character Education Values In Qur'anic Verses “, dalam Jurnal Studi Islam, vol. 17, no. 2, 2016, hlm. 111.

Daud, Wan Mohd Nor Wan, Filsafat dan Praktik Pendidikan Islam Syed M. Naquib Al-Attas, Bandung: Mizan, 2003.

Dzulmanni, Islam Liberal dan Fundamental Sebuah Pertarungan Wacana, Yogyakarta: Elsaq Press, 2007.

Husaini, Adian, "Pendidikan Karakter Berbasis Ta'dib", dalam Jurnal TSAQAFAH, vol. 9, no. 2, 2013, hlm. 377.

Husaini, Adian, Dkk, Filsafat Ilmu; Perspektif Barat dan Islam, Jakarta: Gema Insani Press, 2015.

Husaini, Adian, Muslimlah daripada Liberal, Jakarta: Sinergi Publishing, 2010.

Husaini, Adian, Pancasila Bukan Untuk Menindas Hak Konstitusional Umat Islam, Jakarta: Gema Insai Press, 2009.

Husaini, Adian, Pendidikan Islam Mewujudkan Generasi Gemilang Menuju Negara Adidaya 2045: Kompilasi Pemikiran Pendidikan, Depok: Yayasan Pendidikan Islam At-Taqwa, 2018.

Husaini, Adian, Pendidikan Islam: Membentuk Manusia Berkarakter dan Beradab, Jakarta: Cakrawala Publishing, 2012.

Kersten, Carool, Berebut Wacana: Pergulatan Wacana Umat Islam Indonesia Era Reformasi, Bandung: Mizan, 2018.

Mudlofir, Ali, Aplikasi Pengembangan Kurikulum Tingkat Satuan Pendidikan (KTSP) dan Bahan Ajar dalam Pendidikan Agama Islam, Jakarta: Rajawali Press, 2012. 
Muttaqin, Ahmad, "Rekonstruksi Gagasan Pluralisme Agama: Telaah atas Buku Pluralisme Agama, Musuh-Musuh Agama Karya Adian Husaini", dalam Jurnal Al-AdYan, vol. 9, no. 1, 2014, hlm. 109.

Nasir, Amir, "Sintesis Pemikiran M. Amin Abdullah dan Adian Husaini: Pendekatan dalam Pengkajian Islam", dalam Jurnal Fikrah, vol. 2, no. 1, 2014, hlm. 150.

Nuh, Mohammad, Menyemai Kreator Peradaban: Renungan tentang Pendidikan, Agama dan Budaya, Jakarta: Zaman, 2013.

Nurhayati, Tri Kurnia, Kamus Lengkap Bahasa Indonesia, Jakarta: Eska Media Press, 2005.

Panduan Pelaksanaan Pendidikan Karakter, Jakarta: Kementerian Pendidikan Nasional Badan Penelitian dan Pengembangan Pusat Kurikulum dan Perbukuan, 2011.

Suhartono, Suparlan, Filsafat Ilmu Pengetahuan, Jogjakarta: Ar-Ruzz Media, 2016. Suryadi, Ace, Dkk, Pendidikan untuk Transformasi Bangsa: Arah Baru Pendidikan untuk Perubahan Mental Bangsa, Jakarta: Kompas, 2014.

Syafe'i, Imam, “Tujuan Pendidikan Islam”, dalam Jurnal Al-Tadzkiyyah: Jurnal Pendidikan Islam, vol. 6, no. 2, 2015, hlm. 164-165.

Undang-Undang Nomor 20 Tahun 2003 tentang Sistem Pendidikan Nasional. 